\title{
Fotografi: Sains, Teknologi, Seni, dan Industri
}

\author{
Prayanto Widyo Harsanto \\ Institut Seni Indonesia Yogyakarta \\ Jurusan Desain Komunikasi Visual, Fakultas Seni dan Desain \\ Universitas Kristen Petra, Surabaya \\ E-mail: prayantowh@ymail.com
}

\begin{abstract}
Abstrak
Era fotografi digital merupakan proses kemajuan pengetahuan dan teknologi yang maha dahsyat dalam sejarah fotografi setelah Niepce dan Daguerre pada abad 19 dalam eksperimennya mampu merekam sebuah gambar yang permanen dengan objek pemandangan suasana kota di Perancis. Penemuan ini dianggap paling sempurna di bidang fotografi dibanding sebelumnya. Di era kamera digital, masyarakat memandang fotografi sebagai sesuatu yang mudah, murah, dan merupakan bagian dari kehidupan sehari-hari. Inilah apa yang sering disebut dengan digitalisasi fotografi. Meskipun demikian secanggih apapun peralatan fotografi saat ini namun masih tetap diperlukan seorang fotografer yang memiliki pengetahuan dan kemampuan teknis dengan kepekaan estetis yang baik sebagai 'man behind the camera'. Di era industri kreatif seperti saat ini, fotografi dapat dikatakan berada pada empat aspek (sains, teknologi, seni, dan industri) yang saling berkaitan antara satu dengan yang lain. Sebab masalah fotografi ternyata tidak sesederhana perkara memencet tombol rana (memotret saja), lebih-lebih dalam dunia pendidikan. Pengajaran fotografi tidak hanya dilihat dari sekedar pengajaran tentang penguasaan teknis belaka, yang hanya mengatur diafragma, kecepatan, dan pencahayaan yang tepat saja, tetapi fotografi melibatkan mata, pikiran (pengetahuan dan wawasan), dan rasa dalam menyeleksi sebuah objek dan menyatukan dalam sebuah frame yang disebut sebagai sebuah karya foto. Dan yang tidak kalah penting diperhatikan pula adalah bahwa selain mengajarkan bagaimana cara memproduksi atau membuat foto, sejak awal seharusnya juga diberikan pengetahuan dan pemahaman atas segala kemungkinan aspek pendistribusian setelah foto itu berhasil diproduksi.
\end{abstract}

Kata kunci: Fotografi, sains, teknologi, seni, dan industri.

\begin{abstract}
The digital photography era is a great development in science and technology in the history of photography after Niepce and Daguerre. Where in the $1^{\text {th }}$ century, their experiments lead to the ability to capture images permanently with the subject of a cityscape in France. This discovery was considered most perfect in photography compared to previous ones. In the digital camera era, society views photography as something easy, inexpensive, and a part of everyday life. This is what is called the digitalization of photography. However so sophisticated the photographic equipment there may be today, there is still the need a photographer that has the knowledge and technical skills with good aesthetic sensibilites as "the man behind the camera." In the era of creative industry like today, photography can be said to be in four aspects, which are sciense, technology, art, and industry, that are intertwined. It is because photography is not as easy as pushing the shutter button, even more so in the world of education. The teaching of photography cannot be seen as merely teaching techniques, adjusting apertures, speed, and lighting, but it involves the eyes, thoughts (knowledge and understanding), and feeling in selecting an object and arranging it in a frame of a photograph. Furthermore, what should be considered is that besides teaching how to produce and create a photo, one should know and understand as to every possibilites of aspects of its distribution after the photo has been successfully produced.
\end{abstract}

Keywords: Photography, science, technology, art, industry.

\section{Pendahuluan}

Sekarang ini adalah zaman teknologi informasi, dimana menuntut semua orang untuk bergerak serba cepat, maka tidaklah heran bila untuk mendapatkan sesuatu cara-cara instan sering dilakukan. Segala sesuatu yang ingin dicapai maunya dilakukan dengan serba cepat dan mudah. Kebiasaan ini menjadikan semua hal seolah dapat ditempuh dengan cara instan tanpa 
melalui sebuah proses dan tingkah laku seperti inilah yang sering disebut sebagai "budaya instan". Dan yang menjadi renungan dan sekaligus pertanyaan dalam dunia desain (seni rupa) umumnya dan fotografi pada khususnya saat ini adalah, "Masih pentingkah sebuah teori dan pengetahuan untuk mendasari seseorang dalam berkarya? Atau seberapa pentingkah sebuah proses dalam mencipta sebuah karya?"

Terkait dengan tulisan ini, dalam kurun waktu lima tahun terakhir ini sering terdengar perbincangan tentang permasalahan dalam fotografi di era digital, dan bahkan muncul pendapat sebagian masyarakat yang menyatakan bahwa aktivitas potret-memotret adalah sangat gampang sekali, tinggal pencet, jepret, dan jadilah sebuah gambar yang disebut fotografi. Hampir semua hal yang berkaitan dengan penciptaan seni rupa, termasuk fotografi di era digital yang terjadi saat ini, dianggap sederhana dan mudah. Masyarakat yang dulu menganggap fotografi menjadi suatu pekerjaan yang sulit dan membutuhkan biaya yang mahal, sekarang ini fotografi merupakan pekerjaaan yang mudah dan murah. Dan memang tidak dapat dipungkiri lagi, dulu fotografi merupakan aktivitas yang hanya dapat dilakukan oleh segelintir orang saja, karena untuk bisa menguasai kamera saja butuh keterampilan yang tidak mudah serta waktu yang lama. Belum lagi prosesnya yang rumit dan membutuhkan biaya yang relatif mahal. Maka, dulu tidak setiap orang bisa melakukan pekerjaan menjadi seorang fotografer. Sekarang ini siapa saja bisa melakukan bahkan dapat dikatakan aktivitas memotret tidak lagi mengenal umur, pendidikan, jenis kelamin bahkan status sosial. Perkembangan dunia fotografi saat ini telah mengubah pola kehidupan manusia, kalau dulu fotografi adalah hobi dan profesi, kini fotografi merupakan gaya hidup bagi hampir setiap manusia. Keinginan untuk memiliki kamera sama besarnya dengan keinginan seseorang memiliki handphone/telepon genggam (Kompas, 14 Juli 2009).

Aksi jeprat-jepret dengan kamera digital, secara tidak langsung, menjadi sinyal positif bagi dunia fotografi dewasa ini. Seakan memiliki nilai magis sekaligus magnet bagi masyarakat yang berminat ingin mencoba di bidang fotografi. Era kamera digital pula yang merubah cara kerja, dan paradigma fotografi, yang tidak sesakral di era kamera analog. Sebagaimana yang dikatakan Walter Benjamin (1999), 'aura', telah berlalu. Buktinya, sekarang muncul keyakinan banyak orang bahwa pakem dan teknik fotografi sudah dianggap tidak penting dan tidak harus diindahkan lagi. Tanpa kecuali, semua orang dapat menggunakan kamera digital dan dapat menghasilkan gambar. Kamera digital memang membuat segalanya menjadi mungkin. Memotret memang mudah, tetapi untuk membuat foto yang baik dan indah tidaklah sedemikian mudah, sebab fotografi tidak sekedar mengandalkan alat saja tetapi masih ada hal lain yang lebih penting yakni pengetahuan seperti halnya gagasan/konsep, dan estetika.

Maka tidak dapat dipungkiri lagi bahwa akhirakhir ini hanya dengan bermodalkan kamera digital banyak berdiri usaha fotografi, bahkan semakin ramai dan menjamur. Orang pun banyak menjual jasa dengan kamera digital dari menjadi fotografer panggilan, membuka studio, sampai membuka kursus fotografi. Kamera digital telah memunculkan fotografer-fotografer dadakan, kadang tanpa dibekali pengetahuan mengenai teknik, estetika, dan manajemen, tetapi cukup dengan modal keberanian dan kamera. Inilah yang saat ini menjadikan fotografi sebagai bisnis yang cukup menjanjikan. Namun demikian, bila dikaitkan upaya pemerintah Indonesia yang ingin memajukan industri kreatif, yang salah satunya fotografi sebagai sektor industri kreatif dari 14 sektor, maka kondisi tersebut di atas justru merupakan keprihatinan pemerintah. Sebab sektor industri kreatif terus mengalami perkembangan, bahkan mampu bersaing dengan sektor lain yang lebih mapan. Akan tetapi, ada kelemahan industri kreatif, yakni rendahnya kualitas sumber daya manusia serta penguasaan teknologi. Memang haruslah diakui bahwa hal ini merupakan beban dan menjadi tanggung jawab semua pihak. Bahkan masih ada sejumlah persoalan dan tantangan yang menghadang pertumbuhan industri kreatif di Indonesia, seperti kebutuhan SDM yang terampil, hak cipta, peran pemerintah, dan lain sebagainya.

\section{Metode Penelitian}

Penelitian ini menggunakan penelitian kualitatif. Penelitian kualitatif digunakan agar jalannya penelitian dapat dilakukan secara sistematis sebagai upaya untuk menghimpun, mengidentifikasi, menganalisis, dan mengevaluasi (menyimpulkan) data serta informasi yang diperoleh.

Metode ini ditujukan untuk memperoleh pengetahuan mengenai kemajuan teknologi pada bidang fotografi dan dampak yang ditimbulkan. Karena saat ini, dunia fotografi dapat dikatakan berada pada empat aspek (sains, teknologi, seni, dan industri) yang saling berkaitan antara satu dengan yang lain. Untuk mencapai hal tersebut dilakukan langkah-langkah dengan dua tahapan pokok yang dilakukan dalam penelitian ini yaitu: teknik 
pengumpulan data dan teknik analisis data. Tahapan-tahapan pokok tersebut dapat dijelaskan sebagai berikut:

\section{Teknik Pengumpulan Data}

Metode untuk memperoleh data yang berkaitan dengan hal tersebut di atas, ditempuh langkahlangkah pengumpulan data sebagai berikut:

a. Metode Observasi

Observasi dilakukan dengan cara pengamatan mendalam dan terfokus terhadap objek kajian. Observasi ini dilakukan dengan dua cara, yaitu: (1). Mengamati karya-karya foto yang dihasilkan peserta didik baik yang menggunakan kamera analog maupun yang digital. (2). Observasi dilakukan dengan cara mengamati langsung perilaku yang dilakukan peserta didik dalam memotret dan memprosesnya. Tujuan observasi ini adalah untuk mendapatkan gambaran tentang bagaimana peserta didik (masyarakat) mencipta karya foto di era fotografi digital. Hal ini untuk mengetahui peran sebuah teori dan pengetahuan untuk mendasari seseorang dalam berkarya fotografi.

b. Metode Wawancara

Wawancara atau interview salah satu cara untuk mengumpulkan data dengan cara menanyakan langsung kepada seorang narasumber. Narasumber adalah orang yang benarbenar menguasai permasalahan karena ia telah cukup lama menyatu dengan pekerjaannya dan masih terlibat penuh di dalamnya. Wawancara terhadap subjek merupakan wawancara formal melalui suatu proses wawancara didasarkan atas daftar-daftar pertanyaan yang telah dipersiapkan, maupun berpartisipasi dalam beberapa kegiatan informan (Vredenbregt, 1978).

Dalam penelitian ini yang dijadikan sebagai narasumber adalah para peserta didik (mahasiswa), fotografer dan tokoh-tokoh (pelaku industri). Metode wawancara dalam penelitian ini menetapkan dua narasumber di bidang fotografi Surya Hari Wibawa (34 th), fotografer komersial yang tinggal di Jakarta. Selain narasumber di bidang fotografi, juga menetapkan narasumber di bidang industri (periklanan). Narasumber di bidang industri (periklanan) ditetapkan Kristianto (49 th) sebagai seorang brand and visual communication design consultant tinggal di Jakarta dan Andika Dwijatmiko (36 th) seorang desainer grafis sekaligus pimpinan Syafaat Advertising Yogyakarta.

Teknik yang digunakan dalam melakukan wawancara ini memakai teknik partisipasi terbatas. Dengan teknik ini, peneliti tidak menyem- bunyikan identitas sesungguhnya dan berusaha untuk mengembangkan rapport atau hubungan yang baik dengan para narasumber. Untuk mendapatkan informasi atau data dengan narasumber dilakukan dengan menggunakan beberapa cara, antara lain: (1). Wawancara secara langsung bertemu dengan narasumber, yang sebelumnya telah dipersiapkan daftar pertanyaan yang sesuai dengan data yang dikehendaki. (2). Wawancara dilakukan dengan menggunakan media elektronik. Media elektronik yang digunakan adalah dengan cara melakukan komunikasi secara langsung melalui Telepon dan atau komunikasi melalui jaringan internet (e-mail).

Sebagai pelengkap pengumpulan data, digunakan juga penelitian dari berbagai sumber kepustakaan sebagai upaya untuk memperoleh data sekunder.

\section{Teknik Analisis Data}

Analisis dalam penelitian ini menggunakan tiga tahap kegiatan yang terjadi secara bersamaan dalam menganalisis data yang meliputi reduksi data, penyajian data, dan penarikan kesimpulan/ verifikasi (Miles, 2007: 15-19). Keseluruhan data yang diperoleh dari hasil observasi, wawancara, dan pustaka selanjutnya disusun sesuai kategorikategori yang sesuai dengan tujuan penelitian. Selanjutnya dilakukan reduksi data yang merupakan tahap pertama, reduksi data merupakan bentuk analisis untuk menajamkan, mengarahkan, membuang yang tidak perlu, dan mengorganisir data sehingga kesimpulan final dapat ditarik dan diverifikasi. Tahap ke dua adalah penyajian data (ekspose data), pada penelitian kualitatif pada umumnya berbentuk teks naratif (uraian). Tahap terakhir (tahap ketiga) adalah menarik kesimpulan atau verifikasi, merupakan bagian dari kegiatan konfigurasi yang utuh. Hal ini merupakan interpretasi dan sintesa terhadap fotografi yang terkait antara sains, teknologi, seni, dan industri.

Demikian analisis data yang dilakukan merupakan upaya yang berlanjut, berulang, dan terusmenerus. Penelitian ini akan diakhiri setelah penulis merasa semua data yang dibutuhkan lengkap, serta telah tercapai tingkat kepercayaan terhadap kebenaran data/hasil penelitian.

\section{Fotografi: antara sains, teknologi, dan seni}

Sebagaimana dikatakan oleh Francis Lim (2008), Fotografi adalah perpaduan antara sains, teknologi, dan seni. Sains bergerak dalam wilayah hukum-hukum ilmu pasti. Dengan sains ini fotografi memiliki aspek keterdugaan yang pasti, 
hasil pemotretan pada dasarnya dan sudah dapat diprediksi atau diketahui secara teknis, seperti berapa kecepatan yang digunakan, berapa bukaan diafragma yang dipasang, berapa ukuran lensa, bagaimana pencahayaan, dan lain sebagainya. Fotografi sebagai hasil pengembangan dari sains yang berupa teknologi yang diterapkan senantiasa bergerak pada setiap aspek kehidupan yang menyentuh soal-soal ekonomi, sosial, politik, dan budaya. Sains bergerak dalam wilayah teoretis, sedangkan teknologi dalam wilayah praksis. Sains dan teknologi berjalan bersama-sama karena keduanya saling membutuhkan. Selanjutnya dikatakan pula bahwa teknologi mempunyai ciri 'berpusat-pada-kehidupan' (life-centered), yaitu bertujuan utama mengembangkan kehidupan dan bertujuan menciptakan artefak baru dengan cara meningkatkan keefektifan. Sedangkan dengan seni, fotografi menghasilkan modus produksi baru yang menuntut pendekatan dan cara pandang baru sebagaimana yang diungkapkan Walter Benjamin "karya seni di zaman reproduksi mekanis". Fotografi sebagai salah satu entitas dalam domain seni rupa tidak bisa terlepas dari nilai-nilai dan kaidah-kaidah seni rupa. Reproduksi Mekanik suatu karya seni (the work of art) bagi Benjamin merupakan bagian dari pola representasi yang diproduksi secara terus menerus dengan menggunakan suatu alat mekanis yang meniscayakan kehadirannya dalam ruang dan waktu tertentu. Alat disebutnya sebagai mekanis (mechanism). Sedangkan reproduksi mekanis menurutnya, mengacu pada proses teknis sebuah alat produksi yang mampu menghasilkan karya. Karya ini bisa berupa gambar, Benjamin mencontohkannya dengan kehadiran Fotografi yang menggantikan fungsi Litografi untuk mengambil obyek gambar sesuai 'aslinya'. (Benjamin dalam Ilumination, 1999: 211).

Dengan diturunkannya tiga aspek fotografi (sains, teknologi, dan seni) sebagaimana digambarkan di atas, sudah didapat persoalan yang saling berkaitan antara satu dengan yang lain. Masalah fotografi ternyata tidak sesederhana perkara memencet tombol rana (memotret saja), fotografi tidak juga hanya dilihat sebagai sekedar teknis belaka, yang hanya mengatur diafragma, kecepatan, dan pencahayaan yang tepat saja, tetapi fotografi juga melibatkan mata, pikiran/pengetahuan, dan rasa dalam menyeleksi realitas dan menyatukan dalam sebuah frame secara harmoni, sehingga memiliki nilai dan makna.

Sejarah fotografi mencatat bahwa untuk menghasilkan sebuah foto pada awalnya diperlukan suatu proses yang panjang dan rumit. Generasi selanjutnya, seorang fotografer hanya mampu menghasilkan gambar hitam putih, karena memang pada saat itu belum ada teknologi foto berwarna. Perkembangan lebih lanjut, setelah dunia fotografi mengenal teknologi cetak foto warna, fotografer mulai berkreasi bebas dan memacu kreativitas para fotografer. Namun dengan perkembangan seperti saat ini sebagai masa generasi digital, sebentar lagi akan sampai pada generasi yang tidak lagi mengenal apa kamera analog (kamera yang menggunakan film), apa itu film negatif, apa itu diapositif atau slide, apa itu film ukuran $135 \mathrm{~mm}$ atau $120 \mathrm{~mm}$, dan lain sebagainya. Dan hal ini telah menjadi kenyataan, dimana tahun 2009 Kodak sebagai produsen film yang telah mencatat sejarah panjang dalam dunia fotografi telah menghentikan untuk produksi film seluloid yang merupakan elemen penting bagi kamera analog. Karena apa yang dilakukan fotografer generasi sekarang, begitu memotret yang dia tahu adalah kamera digital. Oleh karena itu, sesungguhnya tidak seharusnya terjadi suatu pertentangan antara memotret dengan kamera analog atau kamera digital. Mengingat esensi fotografi tidak terletak pada alat yang digunakan, melainkan inovasi apa yang dilakukan untuk menghasilkan foto terbaiknya. Sebagaimana yang dikatakan oleh Marc Levey (1980), dalam menciptakan karya fotografi pentingnya menekankan wujud dan isi dalam sebuah karya dua dimensi. Fotografer bertanggung jawab untuk mengkomunikasikan pesan melalui sebuah karya dua dimensi yang disebut fotografi. Karena karya tersebut memiliki fungsi sentral yang simbolis dan komunikatif.

Tidak banyak orang yang memahami dan bisa memanfaatkan fotografi dengan baik, sehingga fotografi mampu memberikan arti penting sebagai salah satu bagian dari hidupnya. Banyak orang beranggapan bahwa fotografi tidak lebih dari sekedar membuat foto-foto keluarga yang sekedar jepret... jepret... jadi dan terlihat gambarnya. Sebenarnya alat-alat fotografi sekarang ini telah banyak memberikan kemudahan bagi setiap orang untuk menciptakan foto yang lebih baik. Fotografi yang kita kenal pun sebenarnya terbagi dalam dua aspek yaitu aspek teknologi dan seni. Namun, ketika terjadi perbincangan kebanyakan orang lebih terkagum-kagum melihat pada teknologinya daripada aspek gagasan maupun estetikanya. Aspek tersebut sangat penting dipahami dan dikuasai oleh siapa saja yang serius dan yang berminat di bidang fotografi. Secara simultan dipelajari mulai dari segi teknis yang terkait dengan teknologi, dan kemudian meningkat pada aspek seni (estetika) dan gagasan yang akan dibangun. 
Memang, untuk mendapatkan hasil yang baik, sudah seharusnya seseorang harus mengenal dan mengikuti perkembangan teknologi fotografi. Dengan mempelajari sejarah fotografi, mengenal perkembangan kamera foto, dan memahami teknologi secara baik maka dapat diharapkan kualitas teknis pemotretan pun akan bagus dan benar. Untuk menghasilkan foto yang baik sebaiknya tidak mempelajari dari seni dulu baru ke teknis/teknologi, karena justru akan menghasilkan konsep visual yang lemah dan cenderung menuju abstraksi yang ngawur. Sebagai contoh ketika akan memotret manusia, jika fotografer tidak mengenal jenis pemakaian lensa maka bisa terjadi distorsi dan obyek foto akan kecewa karena hasil foto tidak sesuai dengan kenyataan, bahkan yang bersangkutan menjadi tidak mengenali wajahnya. Pemotretan seperti ini membutuhkan pemahaman teknologi dan salah satu hasil teknologi tersebut adalah lensa. Kalau fotografer tidak mengenal keunggulan setiap lensa, bagaimana mungkin dapat menghasilkan gambar foto dengan standar mutu yang baik. Selain hal tersebut, masih banyak material dan komponen teknis yang ada pada fotografi. Di era analog seorang fotografer setidaknya harus memahami operasional kamera, jenis film, kamar gelap, lensa serta asesorinya. Sedangkan di era fotografi digital seorang fotografer harus menguasai teknologi yang menyertai seperti operasional kamera, lensa, asesori lain maupun komputer sebagai pengganti kamar gelap. Bila belum menguasai peralatan fotografi, maka seseorang akan mengalami kesulitan untuk mencapai hasil yang baik. Bahkan dapat terjadi hasil foto menjadi tidak tajam, warna kurang cemerlang, pencahayaan tidak maksimal, objek tidak bisa menonjol, dll.

Sesudah menguasai aspek teknis dan teknologi, alangkah baiknya seorang fotografer juga memahami dan menguasai aspek seni dalam fotografi. Sebab karya fotografi adalah berbentuk gambar yang tidak terlepas kaitannya dengan seni rupa. Oleh karena itu, penyajian dan penilaiannya pun tidak terlepas dari kaidah-kaidah yang berlaku umum dalam seni rupa. Namun, perlu disadari bahwa memotret tidak hanya sekedar mengambil gambar, melainkan membuat gambar. Artinya, untuk mendapatkan sebuah foto yang baik banyak hal yang perlu dipelajari, misalnya dari segi teknis fotografi, lighting, pengetahuan estetika atau pengetahuan tentang seni rupa yang baik. Kalau berbicara mengenai fotografi, tidak hanya pada hal yang serba teknis saja, namun banyak hal di luar masalah teknis. Dikatakan Soeprapto Soedjono (2006:7) bahwa fotografi sebagai salah satu entitas dalam domain seni rupa tidak bisa terlepas dari nilai-nilai dan kaidahkaidah seni rupa. Dengan kata lain, meskipun peralatan yang tersedia sangat canggih namun tetap diperlukan kemampuan teknis dan kemampuan estetis yang memadai. Dengan jam terbang yang tinggi dan banyak membaca, serta melihat buku fotografi, masalah teknis fotografi dapat diatasi, tetapi hal yang berkaitan seni rupa dan rasa estetika yang baik tidak dapat dicapai dengan membaca dan melihat saja tetapi harus dengan praktek. Dengan melakukan praktek psikomotorik seperti: olah visual (melukis, nirmana, menggambar, sketsa), artinya kita memindahkan objek yang tiga dimensi ke bentuk dua dimensi. Dengan latihan ini kita belajar melihat dan merasakan bentuk, sinar, bayangan, gradasi, warna, pola, maupun tekstur. Perlu diketahui bahwa fotografi adalah seni melihat (the art of seeing), terjadinya gambar/foto berawal dari mata/melihat. Dasar ilmu melihat ini berlaku untuk ilmu pengetahuan lain. Dikatakan oleh Zahar bahwa dasar seni rupa seperti menggambar, nirmana, anatomi, sejarah seni rupa, bahkan kritik seni sangat penting sebagai bekal untuk belajar fotografi (Zahar, 2003: 101). Sebab prinsip fotografi tidak jauh berbeda dengan menggambar, artinya menggambar sama dengan memotret, dan fotografi berasal dari kata photos (cahaya) dan graphos (menggambar/menggores) yang artinya menggambar dengan cahaya. Melihat dan menyadari arti pentingnya melakukan aktivitas psikomotorik dengan menggambar, merancang nirmana, dan memahami wawasan seni rupa merupakan salah satu bekal untuk bisa membuat foto yang baik. Dengan demikian, seseorang yang belajar fotografi dengan menguasai aspek teknis dan teknologi, serta memahami dan menguasai aspek seni akan lebih cepat menguasai dan lebih baik bila dibanding yang hanya belajar teknik fotografi saja.

Pada umumnya pemotret pemula sering lebih menekankan/fokus pada salah satu aspek dari dua aspek teknologi atau seni. Penekanan yang berlebihan pada aspek tertentu akan membawa suatu konsep yang agak timpang. Hal ini sangat mempengaruhi kekuatan penyajian foto secara keseluruhan. Penekanan pada aspek teknis dan teknologi yang berlebihan akan menghasilkan karya yang baik secara teknis, tetapi tidak istimewa dalam penyajian. Demikian pula apabila pemotret berlebihan dalam aspek seni, seperti permainan lighting berlebih, komposisi yang ekstrim, penggunakaan asesori yang berlebih, kadang justru membingungkan pengamat dan menghasilkan karya yang cenderung abstrak/tidak jelas konsepnya.

Untuk menghindari hal tersebut, seorang fotografer sebaiknya menguasai secara baik kedua aspek ini sehingga dapat saling mengisi untuk 
memperkuat penyajian karya foto. Sebab sebuah karya foto pada umumnya dilihat dan dinilai selain gagasan/idenya juga dari dua hal yang lain yaitu: secara teknis dan seni (estetis). Secara teknis pada umumnya menyangkut kemampuan dan kecanggihan teknologi fotografi untuk menghasilkan kesempurnaan hasil pemotretan melalui kualitas peralatan, material, dan proses. Sedangkan aspek estetis (seni) berkaitan persepsi seseorang dalam menyampaikan suatu pesan dalam wujud gambar. Hal ini merupakan kekuatan dalam penyajian sebuah karya fotografi. Untuk memperoleh kualitas visual yang baik pada umumnya memahami/menguasai kaidah-kaidah seni rupa seperti komposisi, pemilihan objek pemotretan, pencahayaan (kondisi pencahayaan). Kualitas teknis pada selembar foto merupakan syarat yang penting, tetapi jauh lebih penting adalah pada kualitas seninya, sebab di sinilah sebuah foto memiliki kekuatan dan daya tarik yang istimewa. Meskipun demikian, kualitas teknis yang baik akan menyempurnakan penampilan dari sebuah foto. Dikatakan Erik Prasetya (Foto Media, Juli 1996), untuk memudahkan menilai sebuah karya foto yang sedemikian kompleks, ada beberapa hal elementer yang perlu diperhatikan. Salah satunya adalah pada aspek teknis, sebab aspek teknis merupakan unsur elementer yang harus selalu berada pada proporsi tertentu. Dalam sebuah karya foto, semakin teknis kurang diberikan/tidak diperhatikan, semakin dituntut aspek lain yang menonjol, dengan kata lain semakin tema yang diangkat sederhana, maka semakin dituntut kekuatan teknis diberikan untuk bisa mendramatisir sebuah foto. Jadi dapat dikatakan bahwa penampilan foto dengan kualitas teknis dan kualitas visual yang baik akan memberi dampak yang luar biasa terhadap pemirsanya. Dengan demikian, seorang fotografer mampu menampilkan pesan dan karakter dengan dampak yang kuat.

\section{Fotografi dalam ranah industri}

Perkembangan fotografi salah satunya berakibat pada bergesernya tujuan awal dari penemuan alat yang semula hanya merupakan alat untuk melihat peristiwa dan fenomena alam. Selanjutnya berkembang sebagai alat bantu pemindai (tracing) yang digunakan oleh para seniman (pelukis) untuk memudahkan kerja dalam melukis. Selain itu, dengan alat ini juga dapat digunakan untuk mendapatkan tingkat presisi yang tinggi dengan model yang akan digambar. Pada umumnya alat ini digunakan untuk membantu melukis, khususnya gedung (arsitektur) dan model manusia (portrait). Pada saat itu hanya senimanlah (pelukis) yang dapat 'memindahkan realitas' ke dalam kanvas (bentuk dua dimensional).
Bertolak dari kemampuan dan fasilitas yang tersedia dari alat itu, fotografi banyak dimanfaatkan untuk berbagi keperluan komunikasi visual, baik yang menyangkut tujuan untuk meyakinkan suatu fakta maupun untuk menimbulkan suasana kejiwaan tertentu kepada pengamatnya. Menurut Markow (1999) fotografi dapat digolongkan sesuai fungsi dan tujuannya menjadi:

1. Fotografi dokumentasi (documentation photography). Fotografi digunakan untuk merekam peristiwa yang dianggap penting oleh si pemotret. Fotografi dokumentasi lebih mementingkan terekamnya peristiwa ketimbang keharusan untuk menerapkan prinsip-prinsip estetika dalam sebuah foto.

2. Fotojurnalistik (photojournalism). Fotografi Jurnalistik seringkali juga disebut press photo atau foto berita. Foto ini biasanya memberitakan suatu peristiwa yang sedang terjadi di masyarakat yang dibuat sesuai dengan keadaan sebenarnya tanpa manipulasi.

3. Fotografi periklanan (advertising photography). Fotografi Periklanan merupakan salah satu cabang dari fotografi profesional yang lebih banyak berfungsi untuk memenuhi kebutuhan industri dalam periklanan sebagai pengganti ilustrasi dari gambar tangan.

Pendapat yang hampir sama juga diungkapkan oleh Arbain Rambey (Kompas, 8 Januari 2010). Fotografi sesungguhnya terbagi dalam dua ranah, yaitu ranah objektif dan ranah subjektif. Fotografi dalam ranah objektif adalah foto-foto yang tampil sesuai kebutuhan bersama antara pemotret dan yang melihat foto itu. Yang masuk dalam kategori ini adalah foto jurnalistik dan juga commercial photography (foto industri/foto komersial). Fotografi Jurnalistik yang seringkali juga disebut press photo atau foto berita. Foto ini biasanya berfungsi memberitakan suatu peristiwa yang sedang terjadi di masyarakat yang dibuat sesuai dengan keadaan sebenarnya tanpa manipulasi. Ada sebuah kesepakatan tak tertulis dalam ranah ini sehingga seakan sudah ada standar dan kaidah-kaidah yang harus diikuti. Untuk kepentingan dokumentasi, segi terpenting yang diperhitungkan adalah bagaimana teknik fotografi dapat merepresentasikan objek visual, peristiwa nyata seobyektif mungkin sehingga rekaman visual fotografi mempunyai kesanggupan untuk dijadikan bukti atau kesaksian suatu kejadian nyata secara meyakinkan. Fotografi Komersial (foto iklan/foto promosional) merupakan salah satu cabang dari fotografi profesional, lebih banyak berfungsi untuk memenuhi kebutuhan industri dalam periklanan.

Adapun fotografi ranah subyektif adalah fotografi seni (art photography) yang semata dihasilkan oleh 
sang fotografer dengan medium fotografi, apapun bentuknya. Perkara foto itu akan diterima orang atau tidak bukanlah masalah. Yang terpenting dalam konteks ini adalah bagaimana pemotret dapat menyalurkan cita rasa estetiknya melalui bahasa fotografi untuk mencapai efek visual gambar tertentu sebagai refleksi dari ungkapan keindahan yang hendak diwujudkannya. Fotografi layaknya sebuah alat untuk melukis pada seorang seniman lukis, yaitu untuk menciptakan gambar dengan tujuan yang bersifat pribadi seperti mengungkapkan gagasan serta hasrat keindahan.

Penemuan fotografi tidak hanya berhenti sebagai alat dokumentasi dan ekspresi seni saja, tetapi dalam bidang desain grafis, penemuan fotografi mulai merambah dalam dunia percetakan. Seperti disebutkan Meggs (1992:150-153).

"Photography was becoming an increasingly important tool in the reproduction of graphic design. As photo mechanical reproduction replaced handmade plates, illustrator gained a new freedom of expression. Photography gradually monopolized factual document and pushed illustrator away toward fantasy and fiction"

Menjelang abad 20 (1890-an) penemuan fotografi telah digunakan untuk kepentingan industri (desain grafis) di mana ilustrasi berwarna dicetak secara foto mekanis. Reproduksi secara fotomekanis mulai menggantikan peranan tenaga terampil yang berperan memindahkan karya seniman (illustrator) ke dalam plat cetak. Upaya proses pemindahan desain ini yang sebelumnya memakan waktu yang relatif lama (berhari-hari) setelah memanfaatkan fotografi (proses foto) hanya memakan waktu satu hingga dua jam saja. Seiring dengan perkembangan zaman dan saat fotografi telah dikenal masyarakat secara luas, masyarakat mulai memanfaatkan karya fotografi tidak hanya sebagai alat dokumentasi, tetapi juga mulai dimanfaatkan untuk kepentingan dalam dunia periklanan (berpromosi). Fungsi fotografi telah bergeser dari alat dokumentasi menjadi karya dalam mendukung dan melayani kebutuhan industri, yang salah satunya dalam dunia periklanan.

Sebagai alat bantu untuk merekam (menciptakan gambar), peran fotografi di dalam kegiatan dalam mendukung industri sangatlah penting. Sebagaimana disampaikan Andreas Feininger (1970: 6), fotografi sebagai a picture language the newest version of the oldest form of graphic communication. Fotografi bukan saja dapat membantu mempercepat proses penciptaan gambar dengan hasil yang teliti serta realistik, tetapi lebih jauh dari itu ia merupakan bahasa baru di bidang komunikasi visual dengan karakteristiknya sendiri yang berbeda dengan teknik gambar tangan sebagai cara menciptakan gambar yang telah ada sebelumnya. Melalui bahasa fotografi pendekatan komunikasi seperti halnya pada industri periklanan mengalami perkembangan yang memungkinkan ditampilkannya rekaman kejadian nyata secara fotografis ke dalam penyajian pesan iklan untuk memperkuat bukti kesaksian secara visual. Fotografi juga dapat lebih mengkonkretkan pesan dengan menyuguhkan citra yang terkesan realistik sebagai sarana meyakinkan identitas suatu produk secara lebih dapat dipercaya daripada teknik gambar tangan. Perihal fotografi, memang bukan hanya bisa dipahami sebagai alat yang ditemukan oleh dua orang Perancis bernama Joseph Nicéphore Niepce (1765-1833) dan Louis Jacques Mandé Daguerre (1787-1851). Tetapi lebih mendasar, adalah bagaimana teknologi ini sangat mendukung sebuah masyarakat industri untuk dimanfaatkan dalam kepentingan komunikasi visual mengenai segala sesuatu tentang hasil produksinya, baik berupa barang maupun berupa jasa.

\section{Fotografi Digital: Paradigma baru dan per- ubahan perilaku}

Teknologi yang maju demikian pesat membuat cara kerja fotografer masa kini juga ikut berubah dengan cepat. Dikatakan Marshal McLuhan (1967) betapa pentingnya ledakan informasi yang disebabkan oleh perkembangan teknologi percetakan, televisi, dan komputer. Dan ia menyebutkan bahwa satu-satunya yang pasti dalam kehidupan modern adalah perubahan perilaku. Semua ini membuat seorang fotografer dalam bekerja harus mampu merespons perkembangan teknologi. Sebuah penemuan yang dilakukan manusia atas dasar kreativitas di zaman modern pada hakikatnya menjadikan hidup itu lebih mudah, manusia bisa lebih sejahtera, peran tenaga manusia semakin dikurangi, bahkan tergantikan oleh alat ciptaannya. Sebagai contoh yang sederhana, penemuan peralatan makan seperti sendok memberikan jarak antara fisik manusia dengan sesuatu yang akan dimakan, adanya remote control pada TV untuk mengganti chanel/saluran program, tinggal pencet jarak jauh sudah otomatis pindah chanel. Jadi dengan inovasi dan penemuan teknologi maka semakin kecil peran manusia, tenaga manusia dikurangi, cara berpikir juga dikurangi dan berubah, semua dipermudah. Maraknya perkembangan fotografi digital juga mendorong perubahan sikap dan perilaku bagi penggunanya. Fotografi digital memberikan kemudahan kontrol secara penuh 
bagi fotografer, "digital photography gives you total control'. Sebagai contoh adalah ketika memotret menggunakan kamera digital, dari pengambilan gambar hingga pencetakan sepenuhnya berada di tangan fotografer.

Setiap kehadiran sesuatu yang baru biasanya juga akan menimbulkan permasalahan baru. Sesuatu yang baru di sini adalah dengan hadirnya produk teknologi. Demikian pula pada dunia fotografi, dengan munculnya kamera digital, seseorang yang berkecimpung di dalamnya sudah seharusnya melakukan antisipasi, adaptasi, dan harus dapat mengikuti perubahan dan perkembangan teknologi tersebut. Apabila tidak dapat mengikuti, memahami, atau menyesuaikan, maka akan ditinggalkan. Perkembangan teknologi tidak dapat ditolak dan dihentikan, tetapi fotografer justru harus menyikapinya secara bijak mengingat kondisi masyarakat saat ini yang semakin instan minded, yang secara otomatis akan mengidentifikasikan dirinya dengan alat-alat atau kamera yang dapat bekerja dengan cepat, mudah pengoperasiannya, murah biayanya, dan baik hasilnya. Fotografi digital merupakan salah satu inovasi teknologi terbaik dalam dunia fotografi. Kehadirannya telah mengubah paradigma masyarakat yang menganggap bahwa fotografi adalah suatu bidang yang mahal dan sulit untuk dikuasai. Fotografi digital benar-benar bisa memberikan kepraktisan dan kemudahan bagi setiap orang untuk membuat sebuah foto yang bagus. Dengan perkembangan teknologi yang pesat dan beragam fitur untuk membuat foto yang bagus, muncullah sebuah ungkapan bahwa "setiap orang bisa menjadi fotografer profesional".

Dunia fotografi dewasa ini mengalami perkembangan dan perubahan yang maha dahsyat karena terjadinya lompatan teknologi yang sangat cepat. Metamorfosa, begitulah kurang lebih arti dari perubahan yang terjadi secara cepat, baik dari proses, teknik, maupun konsep atau ideologi sebuah karya foto yang demikian pesat sekali pada perkembangan teknologi fotografi saat ini. Dengan perkembangan dan perubahan yang maha cepat ini, langsung maupun tidak langsung juga berpengaruh di dalam perilaku bagi pengguna alat ini.

Kehadiran teknologi berbasis digital telah menciptakan perubahan sikap dan perilaku penggunanya. Di satu sisi membebaskan fotografer dari segala keterbatasan, seketika itu pula juga memanjakan dengan segala kemudahaan. Dengan dimanjakan melalui kemudahan ini maka kalau tidak waspada daya imajinasi fotografer justru dibekukan dan diistirahatkan sehingga daya kreativitasnya dapat menjadi tumpul Sebab ruang berekspresi yang diberikan semakin luas tak terbatas.justru tidak dimanfaatkan secara maksimal karena semua dapat direkayasa dengan kemajuan teknologi yang menyediakan fasilitas maksimal untuk upaya yang minimal. Banyak proses kreatif pada saat pengambilan yang dipotong karena dapat diatasi dengan kecanggihan teknologi. Perubahan dan perkembangan teknologi ini memang membawa manusia kepada kehidupan yang lebih baik dari sisi teknis dan material, namun demikian juga dapat menimbulkan masalah lain sebagaimana disebutkan di atas. Akibat perkembangan dan perubahan tersebut sebagian kelompok masyarakat yang tidak siap menyongsong dan menyesuaikan perkembangaan ini akan tergusur atau tergeser kedudukannya. Manusia dapat kehilangan pekerjaan dan mata pencahariannya. Misalnya, fotografer analog yang tidak siap dengan perubahan ini akan kehilangan mata pencaharian karena masyarakat tidak lagi membutuhkannya. Perubahan yang cepat ini dapat membawa kecemasan yang tinggi, kekerasan, dan keresahan di masyarakat, sebab manusia terlalu memusatkan perhatian pada nilai teknik dan materi pada mayarakat global ini (Erich Fromm, 2001: 2). Manusia sebenarnya mengakui dan memerlukan kemajuan tersebut untuk membawa kepada kehidupan yang lebih baik, namun manusia pun juga harus mampu mengeliminasi setiap dampak yang ditimbulkannya. Manusia harus mampu mengendalikan dan menyesuaiakan diri untuk dapat memasuki kehidupan yang lebih baik. Sebab kemajuan iptek senantiasaa ada dan tidak pernah berakhir, maka kecemasan juga senantiasa selalu ada. Selanjutnya adalah bagaimana kita menghadapinya. Pada akhirnya, anggota masyarakat (desainer, pekerja kreatif, fotografer) yang tidak memiliki pengetahuan dan penguasaan teknologi akan terpinggirkan. Mereka adalah kelompok masyarakat yang kalah dan menderita. Pada era digital ini yang dapat survive hanyalah mereka yang berorientasi ke depan, bijak, dan mampu mengubah pengetahuan menjadi kebijaksanaan.

\section{Penutup}

Fotografi menempati ruang sains, teknologi, seni (budaya) tetapi juga pada wilayah industri. Sains dan teknologi berjalan bersama-sama karena keduanya saling membutuhkan. Sains bergerak dalam wilayah teoretis, sedangkan teknologi dalam wilayah praksis. Teknologi dapat menyingkapkan apa yang berada di wilayah teoretis menjadi nyata, yakni membantu sains membuktikan teorinya. Di sisi lain, sains membantu mengarahkan perkembangan teknologi dengan 
perangkat teorinya. Instrumen dan alat teknologi dirancang sesuai tuntutan teori sains, khususnya dalam perkembangan ilmu pengetahuan kontemporer. Tanpa sains, teknologi tidak berkembang. Demikian juga, tanpa teknologi, sains pun juga tidak berkembang, karena keduanya bersifat komplementer. Oleh karena itu, fotografi merupakan bagian dari peradaban manusia yang disebut dengan kebudayaan atau peradaban. Fotografi merupakan kegiatan yang berpokok pada kreativitas (seni). Kreativitas dapat dipandang sebagai sesuatu yang sangat universal, karena adanya pengaruh ruang, waktu, dan perkembangan teknologi yang tidak luput dari rangkaian aktivitas dalam fotografi. Seiring dengan peradaban dan perkembangan zaman, khususnya bersamaan dengan memuncaknya pengaruh revolusi industri pada abad 19, peranan fotografi tidak sekedar mengabadikan citra alam. Fotografi memiliki peran yang sangat banyak. Selain sebagai sarana dokumentasi, seni ekspresi, fotografi juga merupakan sarana informasi, sarana pendidikan, dan alat penunjang dalam bidang industri (barang dan jasa). Peran fotografi dalam wilayah industri dapat dikatakan tidak diragukan lagi akan peran pentingnya dalam mendukung kemajuan dibidang perekonomian. Dalam bentuk industri barang, fotografi didayagunakan produsen untuk menginformasikan mengenai keberadaan dari produk yang dihasilkan. Sedangkan dilihat peran fotografi dalam bidang jasa, banyak lembaga, perusahaan, atau individu memanfaatkan fotografi untuk kepentingan komunikasi (periklanan, penerbitan, dll), dokumentasi (pernikahan dan event-event yang sejenisnya).

Fotografi dalam ranah industri pada umumnya adalah foto yang diciptakan atas permintaan serta berorientasi untuk komersial. Dalam hal ini foto dokumentasi maupun foto ekspresi dapat menjadi karya foto komersial apabila foto tersebut dibutuhkan, dihargai dan dimungkinkan untuk mendapatkan imbalan. Seseorang melakukan pemotretan dengan alasan dan motivasi untuk mendapatkan penghasilan umumnya untuk kebutuhan biro desain, pernikahan (wedding dan pre wedding), advertising, perusahaan atau lembaga, dll.

Dengan berkembangnya teknologi fotografi digital dan hampir bersamaan dengan berkembang dan gencarnya penggunaan komputer sehingga menjadi tidak asing lagi bagi sebagian besar masya- rakat. Sehingga masyarakat pengguna komputer pun dituntut untuk bisa memotret, menyimpan, mengolah, dan mencetaknya. Di era kamera digital, masyarakat memandang fotografi sebagai sesuatu yang mudah, murah, dan sudah merupakan bagian dari kehidupan sehari-hari. Keadaan seperti sekarang ini sering dikatakan berada pada era digital photography. Namun demikian, meskipun peralatan fotografi saat ini sangat canggih, tetap saja diperlukan seseorang yang memiliki kemampuan teknis dengan kepekaan estetis yang baik sebagai 'man behind the camera' dalam menciptakan fotografi. Artinya pengetahuan mengenai seni rupa (estetika) sangat penting dalam menciptakan karya foto, selain gagasan dan kreativitas yang baik dari seorang fotografer.

\section{Daftar Pustaka}

Arbain Rambey, (8 Januari 2010). Memahami Fotografi Konseptual, Kompas.

Benjamin, Walter. (1999). Iluminations, Pimlico, Random House, London.

Feininger, Andreas. (1970), The Complette Photographer, Thames And Hudson, New York.

Fromm, Erich. (2001), Konsep Manusia Menurut Marx, Pustaka Pelajar, Yogyakarta.

Griand, Giwanda (2004), Panduan Praktis Teknik Studio Foto, Puspa Swara, Jakarta.

Levey, Marc (1980), The Photography Texbook, an imprint of Watson-Guptill Publication, USA.

Lim, Francis (2008), Filsafat Teknologi: Don Ihde Tentang Dunia, Manusia, dan Alat, Kanisius, Yogyakarta.

Markow, Paul (1999), Advertising Photography, Amherst Media Inc., Buffalo, New York.

Meggs, Philip B. (1983), A History of Graphic Design, Viking, USA.

Mihardja, Taufik H, (14 Juli 2009). Reformasi Digital: Tak ada yang bisa mengelak lagi dalam Harian Kompas.

Miles B, Matthew dan A. Michael Huberman (2007), Analisis Data Kualitatif, terjemahan Tjetjep Rohendi Rohidi, Penerbit Universitas Indonesia, Jakarta.

Prasetya, Erik, (Juli 1996). Fotografi dalam konstelasi seni, dalam Majalah Foto Media, No 2, Tahun IV.

Rosenblum, Naomi. (1984), A World History of Photography, Abbeville Press, New York.

Soedjono, Soeprapto. (2006), Pot-Pourri Fotografi, Penerbit Universitas Trisakti, Jakarta. 